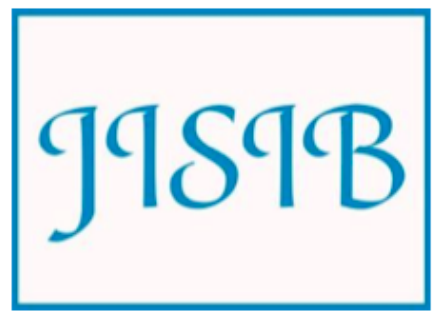

Available for free online at https://ojs.hh.se/

Journal of Intelligence Studies in Business Vol 5, No 2 (2015) 14-21

\title{
Competitive intelligence research: an investigation of trends in the literature
}

\author{
A.S.A. du Toit \\ Department of Information Science, University of Pretoria, South Africa \\ E-mail: adeline.dutoit@up.ac.za
}

Received July 1, accepted September 52015

\begin{abstract}
This article looked at competitive intelligence research reported from 1994 to 2014 in the $A B I /$ Inform database to determine the development of competitive intelligence as subject field. This development can be attributed to several factors. Content analysis was used to establish research patterns and the author based the analysis on the extant literature and on the 338 articles that were gathered from the ABI/Inform database. Only peer-reviewed articles were analysed. The most popular term used in the literature is competitive intelligence, followed by business intelligence and marketing intelligence. The journals in which the articles appeared are scattered and few journals have published more than ten competitive intelligence articles. Few authors have published more than five articles.
\end{abstract}

KEYWORDS: Academic subject field, competitive intelligence, research trends 


\section{Introduction}

Competitive intelligence is not a new business activity but it is a relatively new academic study field (De Pelsmacker, Muller, Viviers, Saayman, Cuyvers \& Jagers 2005, 607). The definition of competitive intelligence is a complicated phenomenon. Similar to many new study fields where coalescence around the domain and scope has not occurred, there are numerous definitions of competitive intelligence but no universal definition (Pellissier \& Nenzhelele 2013). According to Pellissier \& Nenzhelele (2013) a possible universal definition of competitive intelligence is: "A process or practice that produces and disseminates actionable intelligence by planning, ethically and legally collecting, processing and analysing information from and about the internal and external or competitive environment in order to help decision-makers in decision-making and to provide a competitive advantage to the enterprise." With regard to the concept competitive intelligence, "it would seem that there is no commonly accepted term for referring to internal and external intelligence required for business decision-making. Market (or marketing) intelligence, competitive intelligence, business intelligence and other terms are all used at various times to describe more or less the same concept" (Venter \& Tustin 2009, 89).

Competitive intelligence is an interdisciplinary subject field (Walker 1994, 271) and according to Gabriel and Adiele (2012, 27) competitive intelligence is also studied in business management, marketing management, knowledge management and strategic management. Solberg-Søilen (2010, 201) regards competitive intelligence as a subset of integrated marketing communications and Viviers, Saayman, Muller and Calof $(2002,27)$ say that competitive intelligence is a marketing discipline. According to Calof and Viviers (2001, 62) competitive intelligence is a subset of knowledge management.

There is little known about the extent of competitive intelligence research and competitive intelligence as an academic study field. This article will look at the competitive intelligence peerreviewed articles reported from 1994 to 2014 in the $A B I /$ Inform database. The research question, which is the major focus of this article, is: To what extent has competitive intelligence as an academic subject field developed over the past 20 years as reported in the ABI/Inform database? The rationale of the article is to provide a lens of the development of competitive intelligence as an academic study field over the past 20 years. Insights would contribute to a generally under-researched body of competitive intelligence knowledge. The rationale of the article is to provide a lens of competitive intelligence research during a period of 20 years through which to appreciate the prevalence of competitive intelligence in economic and management sciences as it is reflected in the ABI/Inform database.

\section{Contextualising competitive intelligence as subject field}

The field of intelligence originated 500 B.C and competitive intelligence originated from military intelligence (Adidam, Banerjee \& Shukla 2012, 243). According to Powell and Bradford (2000, 184) intelligence dates back more than 5000 years and Fourie (1999) regards Porter's work on strategic management and competitiveness as the main contributor to the development of competitive intelligence as an academic subject field. Before 1980, competitive intelligence literature focused mainly on intelligence gathering for decision making and competitive intelligence as a formal function was only institutionalised as a formal function in the USA in the 1970s and 1980s (Begg \& Du Toit 2007). During the 1990s competitive intelligence grew fast but less attention was given to competitive analysis (Du Toit \& Muller 2005, 321). Fleisher (2000, 14) states that the "CI boom of the last decade was driven by the increasingly widespread recognition that good information has a direct impact on the bottom line." During the 1990s research was done 
that present the watershed between strategic management and competitive intelligence. Competitive intelligence is favoured at the expense of strategic management as a subject field and has evolved over the years as a result of the need for enterprises to scan the complex external environment.

According to Prescott $(1999,41)$ the research emphasis is nowadays on the strategic implications of competitive intelligence. As discussed in the previous paragraphs, competitive intelligence has traditionally been associated with strategic management and knowledge management (Calof \& Viviers 2001, 62) but is nowadays a relatively new academic study field. Competitive intelligence is regarded as the crux of strategic management at an enterprise and enterprises that excel have competitive intelligence as a formal function in their enterprises. The key issues with regard to competitive intelligence research today are the development of intelligence infrastructures for multinational enterprises and the use of social network analysis for intelligence purposes.

Competitive intelligence is a process comprising the following activities (Viviers, Saayman \& Muller 2005, 578-580) - known as the competitive intelligence cycle:

- Planning the collection of information according to key intelligence needs.

- Collection of information from a variety of sources.

- Using analytical tools to analyse the information.

- Packaging of information and communicating it to management.

Some sceptics (for example Weiss 2011) argue that since the late 1990's only a handful of worthwhile competitive intelligence books have been published. Despite its growing popularity dissenting views still linger today. Weiss (2011) argues that the potential contribution of competitive intelligence is often oversold. The other criticisms of competitive intelligence are as follows:

- It is difficult to quantify the direct effect of competitive intelligence in an enterprise (Kahaner 1996, 230), since measuring the benefits of competitive intelligence is more qualitative than quantitative (Industry Canada 2006, 25).

- The effect that competitive intelligence has on an organisation is indirect (Kahaner 1996, 230).

According to Prescott $(1999,39)$, the academic literature of strategic management did not have any impact on the development of competitive intelligence as subject field. The unprecedented growth of competitive intelligence in the last twenty years may be attributed to several factors such as:

- The complexity of the external environment (Hitt, Ireland \& Hoskinsson 2000, 208).

- Recognition that information has an impact on the success of enterprises (Fleisher 2000, 14).

- The increase in the pace of business (Kahaner 1996, 28).

- The increase on the availability of information due to the development of information technology (Kahaner 1996, 29).

- An increase in global competition (Fleisher \& Blenkhorn 2001, 25).

- An increase in the aggressiveness of competition (Kahaner 1996, 31).

- Recognition that competitive intelligence is an essential ingredient of effective management (Shaker \& Gembicki 1999, 18).

- The need for a competitive strategy (West 2001, 28).

Competitive intelligence research has grown in prominence in the last twenty years suggesting that competitive intelligence is a separate function in an 
enterprise and a separate subject field (Adidam, Gojre \& Kejriwal 2009, 669; Calof \& Skinner 1999, 20; Fleisher \& Bensoussan 2007; Kühn 2012). Competitive intelligence has value to all the business activities of an enterprise and the major attraction of competitive intelligence is that it provides actionable foresight regarding competitive dynamics (Prescott 1999, 42).

Since competitive intelligence is an interdisciplinary subject field, competitive intelligence professionals usually have a variety of educational backgrounds and many do have postgraduate degrees (Sewdass \& Du Toit 2014, 187). When these professionals complete a Masters or Doctoral degree, they usually publish an article on the research conducted and valuable competitive intelligence literature can be found in the relevant dissertations and theses.

\section{Content analysis of competitive intelligence articles published in the $A B I / I n f o r m$ database 1995-2014}

To answer the research question, the author examined peer-reviewed competitive intelligence articles in the database ABI/Inform published between 1995 and 2014 and considered the following terms: business intelligence, competitive intelligence, competitor intelligence, marketing intelligence, strategic intelligence and technological intelligence. These terms were published in the title or abstract or subject fields of ABI/Inform. Pendlebury (2010) recommends that when determining the research impact of a subject field, at least five years of research published in publications, should be analysed. Content analysis of the articles was used to establish research patterns of the subject field competitive intelligence (Harrison \& Reilly 2011, 10).

Only peer-reviewed journals were analysed, and not monographs and other vehicles of scholarly communication, since it is agreed that scientific journals publish a significant portion of scientific knowledge in a subject field (Bryman 2006, 115). According to Creswell and Garrett $(2008,323)$ peerreviewed articles are one of the indicators to measure the extent of growth in a subject field.

The term competitive intelligence yielded 11444 references, but the majority of these items were news items and not peer-reviewed articles. A total number of 338 peer-reviewed articles were retrieved. With regard to the term business intelligence, it should be noted that only the articles focusing on the gathering of external information were included. Table 1 lists the terms and the number of articles retrieved for the period.

\begin{tabular}{|l|l|}
\hline Concept & Number of Articles \\
\hline Competitive intelligence & 255 \\
\hline Business intelligence & 44 \\
\hline Marketing intelligence & 27 \\
\hline Strategic intelligence & 5 \\
\hline Technological intelligence & 4 \\
\hline Competitor intelligence & 3 \\
\hline Total number of articles & 338 \\
\hline
\end{tabular}

Table 1: Articles retrieved from ABI/Inform for the period 1995-2014 using selected terms

According to Table 1 the most popular term used in the literature is indeed competitive intelligence, followed by business intelligence and marketing intelligence. The terms competitor intelligence and technological intelligence are not much used in the literature. This indicates competitor intelligence's fall from usage in the favour of competitive intelligence. The research findings showed that the majority of the published articles (72\%) used a descriptive research methodology, followed by case studies $(9 \%)$. This correlates with the statement by Saayman, Pienaar, De Pelsmacker, Viviers, Cuyvers, Muller and Jegers $(2008,384)$ that competitive intelligence articles are mainly descriptive in nature and that few empirical surveys were published. According to Knupfer and McLellan (1996, 1198), descriptive research describes a particular issue or phenomenon and usually answered the what if question. 
The 338 articles were published in 122 journals which indicated the interdisciplinary nature of the subject field. To emphasized this fact, the journals in which the articles appeared are scattered and are as diverse as Global Cosmetic Industry, Internal Auditor, Journal of Legal Studies Education, Journal of Manufacturing Technology Management, Journal of Medical Marketing, Journal of Social, Political, and Economic Studies, Journal of Workplace Learning, Logistics Information Management, Medical Marketing and Media, Mergers and Acquisitions, Pharmaceutical Executive, Security Management, Supply Chain Management Review, Team Performance Management and TQM Magazine. Table 2 lists the journals containing five or more articles retrieved using all of the six related terms mentioned earlier:

\begin{tabular}{|l|l|}
\hline $\begin{array}{l}\text { Journal of Intelligence Studies in } \\
\text { Business }\end{array}$ & 38 \\
\hline Marketing Intelligence \& Planning & 13 \\
\hline $\begin{array}{l}\text { South African Journal of Information } \\
\text { Management }\end{array}$ & 10 \\
\hline European Journal of Marketing & 7 \\
\hline Aslib Proceedings & 5 \\
\hline $\begin{array}{l}\text { Interdisciplinary Journal of } \\
\text { Contemporary Research In Business }\end{array}$ & 5 \\
\hline Searcher & 5 \\
\hline
\end{tabular}

Table 2: Journals with five or more competitive intelligence and related articles retrieved from ABI/Inform for 1995-2014

According to Table 2, a very small number of journals (only three) published a high percentage of competitive intelligence articles and only two journals (Journal of Intelligence Studies in Business and Marketing Intelligence \& Planning) focused exclusively on the publication of intelligence articles. Competitive intelligence literature is this very much scattered and published in dozens of journals.

Competitive intelligence practitioners are very busy and do not write about what they do. The most prolific writers are academics teaching competitive intelligence at institutions of higher education such as J.L. Calof, J.E. Prescott, A.S.A du Toit, S. Wright and W. Viviers (see Table 3). This confirms Solberg
Søilen's $(2014,62)$ statement that most users of JISIB are academics and researchers. Of the 338 articles published, 130 were written by single authors. Most of the authors only published one article on competitive intelligence. As indicated in Table 3, more than $90 \%$ of the authors wrote fewer than five articles.

\begin{tabular}{|l|l|}
\hline AUTHOR & $\begin{array}{l}\text { NUMBER } \\
\text { ARTICLES }\end{array}$ \\
\hline Calof, J.L. & 20 \\
\hline Prescott, J.E. & 17 \\
\hline Du Toit, A.S.A. & 16 \\
\hline Wright, S. & 13 \\
\hline Solberg Søilen, K & 11 \\
\hline Viviers, W. & 11 \\
\hline Fleisher, C.S. & 10 \\
\hline Dou, H. & 9 \\
\hline Muller, M-L. & 9 \\
\hline Martin, S. & 9 \\
\hline Wheaton, K. & 8 \\
\hline McGonagle, J.J. & 8 \\
\hline Gilad, B. & 6 \\
\hline Herring, J.P. & 6 \\
\hline Saayman, A. & 6 \\
\hline Sewdass, N. & 5 \\
\hline Pellissier, R. & 5 \\
\hline
\end{tabular}

Table 3: Authors with five or more competitive intelligence articles as retrieved from ABI/Inform for the period 1995-2014

An analysis of the authorship showed that $43.7 \%$ of the most prolific authors were from the United States, $37.5 \%$ were from South Africa, $12.5 \%$ were from Canada and $6.3 \%$ from France.

The impact of research and a peer-reviewed article is often measured by the number of citations it received. Google Scholar Citations were therefore used to determine the impact of the authors mentioned in Table 3 on the development of competitive intelligence as subject field. Unfortunately the number of citations of the peerreviewed articles of the following authors could not be determined: J.L. Calof, W. Viviers, M.L. Muller, S. Martin, K. Wheaton, J.J. McGonagle, B. Gilad, J.P. Herring, A. Saayman and R. Pellissier since they do not use Google Scholar Citations. Table 4 gives the number of citations of articles by eight authors. 
Table 4 also includes the h-index, which is an indicator of the impact of the publications of an author.

\begin{tabular}{|l|l|l|}
\hline Author & $\begin{array}{l}\text { Number of } \\
\text { citations }\end{array}$ & h-index \\
\hline J.E. Prescott & 6784 & 32 \\
\hline S. Martin & 4599 & 29 \\
\hline C.S. Fleisher & 2047 & 22 \\
\hline H. Dou & 1421 & 16 \\
\hline A.S.A. du Toit & 789 & 12 \\
\hline S. Wright & 772 & 13 \\
\hline $\begin{array}{l}\text { K. Solberg } \\
\text { Søilen }\end{array}$ & 161 & 6 \\
\hline N. Sewdass & 25 & 3 \\
\hline
\end{tabular}

Table 4: Number of citations of peer-reviewed articles

According to Table 4, the authors with the most impact on the development of competitive intelligence as subject field are J.E. Prescott, S. Martin and C.S. Fleisher.

Median is the value above and below around which half of all observations fall. It is a measure of the central location, and it is based on the whole distribution of a variable and not affected by extreme values (Diamantopoulose \& Schlegelmich 2000, 95). According to Table 5, the median number of pages per article for the terms strategic intelligence, competitor intelligence, technological intelligence, marketing intelligence and business intelligence are much higher than for competitive intelligence. Academics are the authors who write longer articles.

\begin{tabular}{|l|l|}
\hline \multicolumn{1}{|c|}{ TERMS } & \multicolumn{1}{|c|}{$\begin{array}{l}\text { MEDIAN NUMBER OF } \\
\text { PAGES PER ARTICLE }\end{array}$} \\
\hline Strategic intelligence & 16 \\
\hline $\begin{array}{l}\text { Competitor } \\
\text { intelligence }\end{array}$ & 15 \\
\hline $\begin{array}{l}\text { Technological } \\
\text { intelligence }\end{array}$ & 12 \\
\hline $\begin{array}{l}\text { Marketing } \\
\text { intelligence }\end{array}$ & 8 \\
\hline Business intelligence & 7 \\
\hline $\begin{array}{l}\text { Competitive } \\
\text { intelligence }\end{array}$ & 5 \\
\hline
\end{tabular}

Table 5: Median number of pages for articles retrieved from ABI/Inform for 1995-2014

\section{CONCLUSION}

This article reviewed competitive intelligence peerreviewed articles published in the ABI/Inform database from 1995 to 2014 to determine the extent competitive intelligence has developed as an academic subject field. The domain of competitive intelligence is broad and competitive intelligence is an interdisciplinary subject field. The articles published are mainly descriptive in nature, followed by case studies and few empirical studies were published. Most of the competitive intelligence articles are published by individual competitive intelligence professionals. Few authors have published more than five articles and few journals have published more than ten competitive intelligence articles.

Content analysis was used to establish research patterns and the author based her analysis on the extant literature and on the 338 articles that were gathered. Content analysis is not without pitfalls and the research could have benefited from a triangulation of research methods. For example, interviews with the 17 authors who have published more than five articles might have provided insights that have been obscured by content analysis. The interviews might have revealed a deeper understanding of trends in competitive intelligence research. This limitation of the research is an opportunity for further research.

Competitive intelligence as subject field deals with relativistic, complex and dynamic social constructs that influence a variety of contexts. More empirical surveys published in peer-reviewed journals provide the possibility to best understand and make assumptions about the complex problems of competitive intelligence as subject field. This will enable competitive intelligence researchers to address all the facets of the complex problems they investigate and will provide a potential for theory 
building since existing theories may not sufficiently provide a framework to understand, explain and predict the new developments in a unique context.

\section{References}

Adidam, P.T., Gajre, S. \& Kejriwal, S. 2009. Crosscultural competitive intelligence strategies. Marketing Intelligence \& Planning 27(5): 666680.

Adidan, P.T., Banerjee, M. \& Shukla, P. 2012. Competitive intelligence and firm's performance in emerging markets: an exploratory study in India. Journal of Business \& Industrial Marketing 27(3):242-254.

Begg, M. \& Du Toit, A.S.A. 2007. Level of importance attached to competitive intelligence at a mass import-retail organization. South African Journal of Information Management 9(4). Available http://www.sajim.co.za. [Accessed 7 January 2015].

Bryman, A. 2006. Paradigm peace and the implications for quality. International Journal of Social Research Methodology 9(2): 111-126.

Calof, J. L. \& Skinner, B. 1999. Government's role in competitive intelligence : what's happening in Canada? Competitive Intelligence Magazine 2(2): 20-23.

Calof, J.L. \& Viviers, W. 2001. Adding competitive intelligence to South Africa's knowledge management mix. Africa Insight 31(2): 61-67.

Creswell, J.W. \& Garrett, A.L. 2008. The movement of mixed methods research and the role of educators. South African Journal of Education 28: 321-333.

De Pelsmacker, P., Muller, M.L., Viviers, W., Saayman, A., Cuyvers, L. \& Jegers, M. 2005. Competitive intelligence practices of South African and Belgian exporters. Marketing Intelligence \& Planning 23(6): 606-620.

Diamantopoulos, A. \& Schlegelmich, B. 2000.

Taking the fear out of data analysis. Hampshire: Cengage Learning EMEA.
Du Toit, A.S.A. \& Muller, M.L. 2005. Training competitive intelligence analysts via the Web: the University of Johannesburg experience. Journal of Education for Library and Information Science 46 (4): 320-332.

Fleisher, C.S. 2000. An introduction to the management and practice of competitive intelligence (CI) in Managing Frontiers in CI. Edited by C.S. Fleisher \& D.L. Blenkhor. Available http://www.questia.com/PM.qst?G$+\mathrm{d}=101031511$ [Accessed 10 February 2015].

Fleisher, C.S. \& Bensoussan, B.E. 2007. Business and competitive analysis. Upper Saddle River, N.J: FT Press.

Fleisher, C.S. \& Blenkhorn, D.L. 2001. Managing frontiers in competitive intelligence. Connecticut: Quorum Books.

Fourie, L.C.H. 1999. World-Wide Web as an instrument for competitive intelligence in a tertiary educational environment. South African Journal of Information Management 1(2/3. Available www.sajim.co.za. [Accessed 6 January 2015].

Gabriel, J.M.O. \& Adiele, K.C. 2012. Competitive Intelligence as panacea for environmental vagaries in Nigeria. Economic Journal of A 2 Z 1(1): 25-30.

Harrison, R.L. \& Reilly, T.M. 2011. Mixed methods design in marketing research. Qualitative Market Research: An International Journal 14(1): 7-26.

Hitt, M., Ireland, R. \& Hoskinsson, R. 2000. Case notes for strategic management: competitiveness and globalization. Annotated Textbook 4(1): 208.

Industry Canada. 2006. Competitive intelligence. Ottawa: Business Service Centre.

Kahaner, L. 1996. Competitive intelligence - how to gather, analyse, and use information to move your business to the top. $7^{\text {th }}$ ed. New York: Touchstone.

Knupfer, N.N. \& McLellan, H. 1996. Descriptive research methodologies. In D.H. Jonassen (ed). Handbook of research for educational 
communications and technology. New York:

Macmillan: 1196-1212.

Kühn, M-L. 2012. Competitive intelligence: the key to intelligent business. Somerset-West: Mediator Printers.

Pellissier, R. \& Nenzhelele, T.E. 2013. Towards a universal definition of competitive intelligence. South African Journal of Information Management 15(2). Available http://dx.doi.org/10.4102/sajim.v15i2.559.

Pendlebury, D.A. 2010. White paper: using bibliometrics in evaluating research. Philadelphia, PA: Thomson Reuters.

Prescott, J.E. 1999. The evolution of competitive intelligence - designing a process for action. Proposal Management Spring: 37-52.

Saayman, A., Pienaar, J., De Pelsmacker, P., Viviers, W., Cuyvers, L., Muller, M.L. \& Jegers, M. 2008. Competitive intelligence: construct exploration, validation and equivalence. Aslib Proceedings: New Perspectives 60(4): 383-411.

Sewdass, N. \& Du Toit, A.S.A. 2014. Current state of competitive intelligence in South Africa. International Journal of Information Management 34(2): 185-190.

Shaker, S.M. \& Gembicki, M.P. 1999. The warroom guide to competitive intelligence. New York:

McGraw-Hill.
Solberg Søilen, K. 2014. A survey of users' perspectives and preferences as to the value of JISIB - a spot-check. Journal of Intelligence Studies in Business 4(2): 61-67.

Solberg Søilen, K. 2010. Boosting innovation and knowledge through delocalization: market intelligence at trade shows. Problems and Perspectives in Management 8(3): 200-207.

Venter, P. \& Tustin, D. 2009. The availability and use of competitive and business intelligence in South African business organisations. Southern African Business Review 13(2):88-117.

Viviers, W., Saayman, A. \& Muller, M.L. 2005. Enhancing a competitive intelligence culture in South Africa. International Journal of Social Economics 32(7): 576-589.

Viviers, W., Saayman, A., Muller, M.L. \& Calof, J. 2002. Competitive intelligence practices: a South African study. South African Journal of Business Management 33(3): 27-37.

Walker, T.D. 1994. The literature of competitive intelligence. Library Trends 43(2): 271-284.

Weiss, A. 2011. Aware online magazine. Available http://www.quora.com [Accessed 17 August 2014].

West, C. 2001. Competitive intelligence. New York: Palgrave. 